\title{
Effects of Palm Oil Mill Effluent on Soil Microflora and Fertility in Calabar - Nigeria
}

\author{
M. L. Iyakndue ${ }^{1}$, A. A. Brooks ${ }^{1}$, A. A. Unimke ${ }^{1 *}$ and B. E. Agbo ${ }^{1}$ \\ ${ }^{1}$ Department of Microbiology, Faculty of Biological Sciences, University of Calabar, P.M.B. 1115, \\ Calabar, Cross River State, Nigeria.
}

\section{Authors' contributions}

This work was carried out in collaboration between all authors. Authors $A A B$ and $M L I$ designed the study, performed the statistical analysis, wrote the protocol and wrote the first draft of the manuscript. Authors AAU and BEA managed the analyses of the study and prepared the final manuscript. All the authors managed the literature searches. All authors read and approved the final manuscript.

Article Information

DOI: $10.9734 / A J O B / 2017 / 33015$

Editor(s):

(1) Mostafa Helmy Mostafa, Prof. of Plant Pathology, Faculty of Agriculture, Ain Shams University, Egypt.

Reviewers:

(1) Abigail I. Ogbonna, University of Jos, Nigeria. (2) Tonjock Rosemary Kinge, The University of Bamenda, Cameroon.

(3) Charles O. Nwuche, University of Nigeria, Nsukka, Nigeria.

(4) P. N. Palanisamy, Kongu Engineering College, India

Complete Peer review History: http://www.sciencedomain.org/review-history/19194

Original Research Article

Received $27^{\text {th }}$ March 2017

Accepted $14^{\text {th }}$ May 2017

Published 25 ${ }^{\text {th }}$ May 2017

\begin{abstract}
In the present study, an agricultural soil artificially amended with different concentrations of palm oil mill effluent was analysed to determine its impact on the soil microflora and other properties such as $\mathrm{pH}$, organic matter, electrical conductivity, and mineral elements. In the polluted soils, the total heterotrophic bacteria, total heterotrophic fungi and total heterotrophic actinomycetes decreased significantly $(p \leq 0.5)$ with increase in the concentration of the pollutant. The total heterotrophic bacteria and total heterotrophic fungi showed significant reduction $(p \leq 0.5)$ with increase in the duration of the pollution while total heterotrophic actinomycetes showed no significance difference $(p \geq 0.5)$ over the duration of pollution. Suspected bacterial isolates from the polluted soils were Pseudomonas sp., Bacillus sp., Staphylococcus sp., Micrococcus sp. Flavobacterium sp., Serratia sp., Proteus sp., while the suspected fungal isolates were Mucor spp., Penicillum spp., Aspergillus spp. and Rhizopus spp. There were significant differences $(\mathrm{p} \leq 0.5)$ in soil $\mathrm{pH}$, organic matter, total nitrogen, potassium, magnesium, available phosphorus and base saturation of the polluted soil and
\end{abstract}


that of the control while the values of sodium, calcium, exchangeable acidity and electrical conductivity of the polluted soil did not show significant difference with that of the control. There was rather a steady increase which was not statistically different from the control with increase in concentration of the pollutant. The results of this study revealed that soil polluted with little quantities of palm oil mill effluent could enhance microbial proliferation and thus, increase soil fertility, while a heavy application inhibits the same.

Keywords: Effect; effluent; palm oil; microflora; fertility.

\section{INTRODUCTION}

The world has entered a period of unprecedented environmental change as evidenced in the rapid growth of natural and man-made changes in the biosphere in recent times. Environmental Pollution resulting in changes in environmental quality is one of the issues raising widespread alarm. An increase in socio-economic activities worldwide has been accompanied by an even faster growth in pollution stress. This is because the majority of human needs can only be met with goods and services provided by industries. Industries have the capacity to improve as well as degrade the environment. Raw materials, which have been taken from the natural resource base, are converted into products by the industry. Lang [1] reported that during the production process pollutants are often released into the environment.

Soil is an efficient purifying medium with a great capacity to receive and decompose wastes matter by its microflora yielding nutrients in the process [2]. However, if the input of the pollutants exceeds the soil purifying limit, the effectiveness of soil microbial activity is reduced considerably. As a result, there will be an adverse change in the soil physicochemical properties which consequently affect the growth and development of the crop plants.

Industrial effluents as pollutants contain a large number of both known and unknown substances formed during the production process. There is a direct impact of pollutants on minerals, organic matter and microbial community of soil [2]. The discharge of industrial effluents especially without treatment may have profound influence on physicochemical and biological properties of soil related to soil fertility. The palm oil industry is a major agro based industry in Nigeria especially in the Southern part where palm oil trees are found both in the wild and plantations. During processing of the ripe fruits to extract the oil, a lot of waste water called palm oil mill effluent (POME) is generated. It is estimated that for 1 tonne of crude palm oil produced, 5 - 7.5 tonnes of water ends up as POME [3]. The solid waste products that result from the milling operation are empty fruit bunches, palm fibre, and palm kernel. Much of the POME results from water used in processing $[4,5]$. Reports indicate that most of the POME is not treated before being discharged into the surrounding environment especially by the small scale mills, causing pollution problems.

POME, if untreated, contains high amounts of fatty acids, proteins, carbohydrates and other plant materials $[6,7,8]$. It alters the environmental parameters such as biological oxygen demand, dissolved oxygen, carbon/nitrogen ratio and chemical oxygen demand as well as moisture content and general soil quality [5]. This has been supported by many researchers $[9,10]$. These parameters affect soil microbial flora which in turn affects soil fertility [11]. Soil fertility is a very important factor, considering the type of use a soil can be put into agriculturally. The raw or partially treated POME has an extremely high content of degradable organic matter, which is due in part to the presence of unrecovered palm oil [3]. This highly polluting wastewater can, therefore, cause pollution of waterways due to oxygen depletion and other related effects as reported by some researchers [3]. Thus, while enjoying a most profitable commodity, palm oil, the adverse environmental impact from the palm oil industry cannot be ignored. It has been observed that most of the POME produced by the small-scale traditional operators undergoes little or no treatment and is usually discharged into the surrounding environment.

In recent years, economic boom in fast developing countries has been witnessed with spectacular progress in industrialization which has resulted in an increased generation of industrial wastes such as liquid, solid and volatile organic gases [3]. In an attempt to dispose of these, man has carelessly polluted the environment. These reasons have made it justifiable to assess the effects of POME on the microbial populations of the soil which enhances soil fertility. 
The general objective of this study was to assess the effects of POME on microbial population and physicochemical properties of an agricultural soil.

\section{MATERIALS AND METHODS}

\subsection{Experimental Design}

The soil sample used in this study was an agricultural soil collected from the botanical garden in the University of Calabar. The pollution of the soil was performed artificially with four concentrations $(0 \mathrm{ml}, 250 \mathrm{ml}, 500 \mathrm{ml}, 1000 \mathrm{ml}$ and $2000 \mathrm{ml}$ ) of palm oil mill effluent in a completely randomized manner and the duration of this study was sixteen weeks.

\subsection{Collection of Samples}

\subsubsection{Soil sample}

Soil samples of $0-15 \mathrm{~cm}$ depth were collected $(5 \mathrm{~kg})$ from five locations on an agricultural soil within university of Calabar by excavation using spade. The collected samples from all locations were thoroughly mixed on the spot in order to obtain composite sample. $5 \mathrm{~kg}$ of this soil was weighed into four different polythene bags [12].

\subsubsection{Palm oil mill effluents samples}

Palm Oil Mill Effluents (POME) were collected from Obasanjo's palm oil mill factory MfamosingAkamkpa, in Cross River State, Nigeria. The sample was collected with clean plastic containers rinsed several times with the same sample and transported within 24 hours to the Department of Soil Science, University of Calabar for analyses and treatment.

\subsubsection{Pollution of the soil sample}

Pollution of the soil was achieved by employing standard methods [13]. $0 \mathrm{ml}, 250 \mathrm{ml}, 500 \mathrm{ml}$, $1000 \mathrm{ml}$ and $2000 \mathrm{ml}$ of the effluent was added to $2 \mathrm{~kg}$ of already dried soil in each polythyene and mixed thoroughly for even distribution. These polluted soil and the unpolluted soil (control) were left outside under normal environmental condition for the duration of 16 weeks (four months).

\section{$\underline{\text { 2.2.4 Microbial analysis }}$}

Microbial analysis was carried out before and after pollution. $10 \mathrm{~g}$ of soil sample was collected aseptically, labelled and stored in ice packed plastic coolers and transported to the Microbiology Department Laboratory University of Calabar where microbial analysis was carried out within 24 hours of sampling so as to maintain the stability of the sample without significant alteration in the microbial population [13].

\subsubsection{Dilution}

Serial dilution was carried out by weighing $10 \mathrm{~g}$ of soil in to $90 \mathrm{ml}$ of sterile saline water contained in a stoppered $200 \mathrm{ml}$ volumetric flask and agitated to dislodge the microorganisms from the soil particles. From this initial dilution, a ten-fold serial dilution was prepared.

\subsubsection{Enumeration of heterotrophic bacteria}

The counts of total heterotrophic bacteria in the soil samples were determined by pour plating 1 $\mathrm{ml}$ of $10^{-5}$ dilutions into nutrient agar (NA). The medium was incorporated with antifungal agent (50 $\mu \mathrm{g} / \mathrm{ml} \mathrm{Nystatin),} \mathrm{in} \mathrm{order} \mathrm{to} \mathrm{prevent} \mathrm{the}$ growth of fungal contaminants. Bacterial colonies were counted after 24 hours of incubation at room temperature and reported as colony forming units (cfu/g) of soil [14].

\subsubsection{Enumeration of heterotrophic fungi}

The total heterotrophic fungi count was measured by pour plating $1 \mathrm{ml}$ of $10^{-3}$ dilution into Sabouraud Dextrose Agar (SDA) supplemented with antibacterial agents $(50 \mu \mathrm{g} / \mathrm{ml}$ of streptomycin and $30 \mu \mathrm{g} / \mathrm{ml}$ of penicillin) to inhibit the growth of bacterial contaminants. Fugal counts were reported after 72 hours of incubation [14].

\subsubsection{Enumeration of heterotrophic actinomy- cetes}

Enumeration of total actinomycetes was achieved by pour plate technique. $1 \mathrm{ml}$ of $10^{-2}$ dilution was plated unto sodium caseinate agar, $50 \mu \mathrm{g} / \mathrm{ml}$ of nystatin and $30 \mu \mathrm{m} / \mathrm{ml}$ of tetracycline was added to inhibit fungal and bacterial growth. An actinomycetes count was reported 7 days after incubation at room temperature $[5,15]$.

\subsubsection{Maintenance of pure isolates}

Bacterial colonies were repeatedly transferred to freshly prepared nutrient agar plates by the streak-plate method and allow growing for 48 hours before stocking. Similarly, distinct fungal 
and actinomycetes colonies were sub-cultured repeatedly on freshly prepared Sabouraud Dextrose Agar plates and sodium caseinate agar, respectively. Pure isolates of the microorganisms were maintained on agar slants as stock, which were preserved in the refrigerator for further use.

\subsubsection{Characterization and identification of isolates}

Various methods were used to characterize and identify the isolates $[14,16,17]$. The test results for bacteria were evaluated using characteristics presented in Bergy's Manual of Determinative Bacteriology [16].

Representative colonies of fungal isolates were characterized and identified based on their cultural and morphological features. The characterizations were achieved through staining techniques-using lactophenol in cotton blue $[14,16,17]$.

\subsubsection{Soil physicochemical analysis}

Physicochemical analysis of the pristine soil was carried out before and after pollution with varying concentrations of the oil mill effluent. Also physiochemical analysis of each soil sample polluted with different concentrations of each effluent was also carried out bimonthly (every 8 weeks). Physicochemical analysis was assessed in terms of the following parameters:

\subsubsection{Particle size and textural class analysis}

In carrying out this test, the Bouyoucos-type hydrometer method was used [18].

\subsubsection{Soil $\mathrm{pH}$}

Soil $\mathrm{pH}$ was determined in water 1:2 soils: water ratio using $\mathrm{pH}$ meter with glass electrode. $20 \mathrm{~g}$ of air-dried soil was weighed into a $50 \mathrm{ml}$ beaker, and $20 \mathrm{ml}$ of sterile saline water was added and allowed it to stand for 30 minutes. The electrode of the $\mathrm{pH}$ meter was inserted into the 1:2 soil /water partly settled suspension and measured the $\mathrm{pH}$. The result was recorded as soil $\mathrm{pH}$ measure in water [17].

\subsubsection{Electrical conductivity (EC)}

In the same soil solution (1:2 soil /water solution) for $\mathrm{pH}$ determination, electrical conductivity electrode was inserted into the partly settled suspension and the EC was measured [17].

\subsubsection{Organic matter}

This wasdetermined by the dichromate wetoxidation method [19].

\subsubsection{Total nitrogen}

Total nitrogen was determined by the microKjeldahl method [20].

\subsubsection{Available phosphorus}

Available phosphorus was extracted with acid fluoride using Bray P-1 method [21]

\subsubsection{Exchangeable cations}

The bases were extracted with neutral $\mathrm{NH}_{4} \mathrm{OAC}$. Calcium and magnesium were determined in the extract by EDTA titration, and potassium and sodium by the use of flame photometer [22].

\subsubsection{Exchangeable acidity}

$\mathrm{A}+$ and $\mathrm{H}+$ were obtained by leaching the soil with $\mathrm{INKCl}$ solution and the extract titrated with standard $\mathrm{NaOH}$ as described by I.I.T.A (1979).

Exchangeable acidity $(\mathrm{Al}+\mathrm{H})-$ Exchangeable $\mathrm{Al}=$ Exchangeable $\mathrm{H}$

\subsubsection{Effective cation exchange capacity}

This was determined by calculation. That is, total exchangeable bases $(\mathrm{Ca}+\mathrm{Mg}+\mathrm{Na})+$ Exchangeable acidity (EA).

\subsubsection{Percentage base saturation}

This will be achieved by dividing the total exchangeable bases by exchangeable cation capacity and multiplied by 100 [6].

$$
\begin{aligned}
& \% \text { base saturation }= \\
& \frac{\text { Summation of exchangeable bases } \times 100}{\text { ECEC }}
\end{aligned}
$$

\subsection{Statistical Analysis}

All statistical analysis of data from various treatments was carried out using analysis of variance (ANOVA) test using factorial experiment. Means were separated using least significance difference (LSD). 


\section{RESULTS}

\subsection{Microbial Analyses}

Table 1 below shows the enumeration of total heterotrophic bacteria (THB), total heterotrophic fungi (THF) and total heterotrophic actinomycetes (THA) in the pristine soil. The counts obtained were as follows $1.90 \pm 1.41 \mathrm{x}$ $10^{7} \mathrm{cfu} / \mathrm{g}, 1.29 \pm 1.25 \times 10^{5} \mathrm{cfu} / \mathrm{g}$ and $9.2 \pm 1.25$ $\times 10^{3} \mathrm{cfu} / \mathrm{g}$ respectively.

\section{Table 1. Total microbial counts of the soil before the commencement of the study}

\begin{tabular}{lc}
\hline THB $(\mathrm{cfu} / \mathrm{g})$ & $1.90 \pm 1.41 \times 10^{\prime}$ \\
THF $(\mathrm{cfu} / \mathrm{g})$ & $1.29 \pm 1.25 \times 10^{5}$ \\
THA (cfu/g) & $9.2 \pm 1.25 \times 10^{3}$ \\
\hline Key:THB = Total heterotrophic bacteria, THF= Total \\
\multicolumn{2}{c}{ heterotrophic fungi, } \\
actinomycetes, cfu/g = Total heterotrophic
\end{tabular}

Table 2 shows the effect of different concentrations of palm oil mill effluent on microbial population of POME- polluted soil. The results obtained for THB in $250 \mathrm{ml}, 500 \mathrm{ml}, 1000$ $\mathrm{ml}$ and $2000 \mathrm{ml}$ were $1.59 \pm 1.84 \times 10^{7} \mathrm{cfu} / \mathrm{g}$, $1.24 \pm 1.40 \times 10^{7} \mathrm{cfu} / \mathrm{g}, 7.0 \pm 1.38 \times 10^{6} \mathrm{cfu} / \mathrm{g}$ and $5.9 \pm 1.22 \times 10^{6} \mathrm{cfu} / \mathrm{g}$ respectively. The results showed that there was no significant difference $(p \leq .05)$ in the mean counts of THB obtained in $250 \mathrm{ml}$ and $500 \mathrm{ml}$, and no significant difference $(p \leq .05)$ was also observed in THB counts of $1000 \mathrm{ml} 2000 \mathrm{ml}$ of the polluted soil (Table 2).
The results for the counts of THF in different concentrations showed that there was a significant increase $(p \leq 0.05)$ in total heterotrophic fungi (THF) counts of $250 \mathrm{ml}$ and $500 \mathrm{ml}$ with mean counts of $2.02 \pm 3.00 \times 10^{5}$ $\mathrm{cfu} / \mathrm{g}, 1.71 \pm 1.89 \times 10^{5} \mathrm{cfu} / \mathrm{g}$ respectively over the control, and a significance reduction $(p \geq 0.5)$ in THF counts of $1000 \mathrm{ml}$ and $2000 \mathrm{ml}$ with mean counts of $1.07 \pm 1.26 \times 10^{5} \mathrm{cfu} / \mathrm{g}$ and $5.1 \pm 1.42 \times$ $10^{4} \mathrm{cfu} / \mathrm{g}$ respectively (Table 2 ).

The total heterotrophic actinomycetes (THA) counts in different concentrations showed that, there was a significant difference $(P \leq 0.5)$ in THA counts among the concentrations. There was a significant increase $(p \leq 0.5)$ in THA counts in 250 $\mathrm{ml}$ and $500 \mathrm{ml}$ with mean counts of $1.33 \pm 2.09 \mathrm{x}$ $10^{4} \mathrm{cfu} / \mathrm{g}, 1.41 \pm 1.84 \times 10^{4} \mathrm{cfu} / \mathrm{g}$ respectively over the control with mean count of $8.9^{b} \pm 1.73 x$ $10^{3} \mathrm{cfu} / \mathrm{g}$ while there was no significance $(p \geq 0.5)$ in THA in $1000 \mathrm{ml}$ and $2000 \mathrm{ml}$ with mean counts of $4.8 \pm 1.16 \times 10^{3} \mathrm{cfu} / \mathrm{g}$ and $3.6^{\mathrm{b}} \pm 1.09 \times 10^{3}$ $\mathrm{cfu} / \mathrm{g}$ respectively over the control (Table 2 ).

Table 3 shows the effect of POME and duration of pollution on microbial populations. The total heterotrophic bacteria (THB) counts after 8 weeks and 16 weeks of pollution were $1.62 \pm$ $4.21 \times 10^{7} \mathrm{cfu} / \mathrm{g}$ and $7.84 \pm 0.98 \times 10^{6} \mathrm{cfu} / \mathrm{g}$ respectively. Significant reduction $(p \geq 0.5)$ was observed in 16 weeks of pollution (Table 3). Also the counts obtained for total heterotrophic fungi (THF) after 8 weeks of pollution produced a mean count of $1.56 \pm 3.81 \times 10^{5} \mathrm{cfu} / \mathrm{g}$ was

Table 2. Effects of concentrations of pollution on microbial population in palm oil mill polluted soils

\begin{tabular}{llllll}
\hline & $\mathbf{0} \mathbf{~ m l}$ & $\mathbf{2 5 0} \mathbf{~ m l}$ & $\mathbf{5 0 0} \mathbf{~ m l}$ & $\mathbf{1 0 0 0} \mathbf{~ m l}$ & $\mathbf{2 0 0 0} \mathbf{~ m l}$ \\
\hline THB $\left(\mathrm{cfug}^{-1}\right)$ & $1.89^{\mathrm{a}} \pm 2.90 \times 10^{7}$ & $1.59^{\mathrm{a}} \pm 1.84 \times 10^{7}$ & $1.24^{\mathrm{a}} \pm 1.40 \times 10^{7}$ & $7.0^{\mathrm{b}} \pm 1.38 \times 10^{6}$ & $5.9^{\mathrm{b}} \pm 1.22 \times 10^{6}$ \\
THF $\left(\mathrm{cfug}^{-1}\right)$ & $1.26^{\mathrm{c}} \pm 2.51 \times 10^{5}$ & $2.02^{\mathrm{b}} \pm 3.00 \times 10^{5}$ & $1.71^{\mathrm{b}} \pm 1.26 \times 10^{5}$ & $1.07^{\mathrm{c}} \pm 1.26 \times 10^{5}$ & $5.1^{\mathrm{d}} \pm 1.42 \times 10^{4}$ \\
THA $\left(\mathrm{cfug}^{-1}\right)$ & $8.9^{\mathrm{b}} \pm 1.73 \times 10^{3}$ & $1.33^{\mathrm{a}} \pm 2.09 \times 10^{4}$ & $1.14^{\mathrm{a}} \pm 1.84 \times 10^{4}$ & $4.8^{\mathrm{b}} \pm 1.16 \times 10^{3}$ & $3.6^{\mathrm{b}} \pm 1.09 \times 10^{3}$ \\
\hline Key: means with the same letter along the horizontal arrays indicates significant difference $(P \leq 0.5)$, and means \\
with different letter along the column indicates no significance difference $(P \geq 0.5)$ \\
THB = Total heterotrophic bacteria, THF= Total heterotrophic fungi, THA= Total heterotrophic actinomycetes, \\
cfu/g = Colony forming unit/gram
\end{tabular}

Table 3. Effects of duration of pollution on microbial population

\begin{tabular}{llll}
\hline & $\mathbf{8}$ weeks & $\mathbf{1 6}$ weeks & LSD \\
\hline THB $\left(\mathrm{cfu} / \mathrm{g}^{-1}\right)$ & $1.62 \pm 4.21 \times 10^{\mathrm{a}}$ & $7.84 \pm 0.98 \times 10^{6 \mathrm{~b}}$ & 2.69 \\
THF $\left(\mathrm{cfu} / \mathrm{g}^{-1}\right)$ & $1.56 \pm 3.81 \times 10^{\mathrm{ba}}$ & $1.07 \pm 2.06 \times 10^{\mathrm{bb}}$ & 3.38 \\
THA $\left(\mathrm{cfu} / \mathrm{g}^{-1}\right)$ & $9.4 \pm 1.28 \times 10^{3 \mathrm{~b}}$ & $7.4 \pm 1.11 \times 10^{3 \mathrm{~b}}$ & 4.04 \\
\hline
\end{tabular}

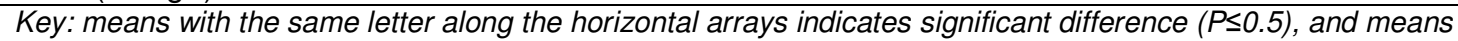
with different letter along the column indicates no significance difference $(P \geq 0.5)$

$T H B=$ Total heterotrophic bacteria, $T H F=$ Total heterotrophic fungi, $T H A=$ Total heterotrophic actinomycetes, cfu/g = Colony forming unit/gram, $L S D=$ Least significant difference 
significantly higher than the THF counts after 16 weeks of pollution with a mean count of $1.07 \pm$ $2.00 \times 10^{5} \mathrm{cfu} / \mathrm{g}$ (Table 3 ). And for the effect of duration of pollution on total heterotrophic actinomycetes (THA) counts obtained, there was no significant difference $(P \geq 0.5)$ in the count obtained after 8 weeks and 16 weeks of pollution.

\subsection{Characterization and Identification of Microbial Isolates}

Microbial isolates were characterized and identified based on their morphological and biochemical characteristics. The following bacteria were isolated from POME polluted soil; Pseudomonas spp., Serratia spp., Bacillus spp., Micrococcus spp., Proteus spp., while the fungal isolates were Rhizopus spp., Aspergillus spp., Mucor spp., Penicillium spp.

\subsection{Soil pH}

The $\mathrm{pH}$ values of the control $(0 \mathrm{ml})$ soils were in the range of $5.66 \pm 0.50$ to $5.7 \pm 0.21$. The $\mathrm{pH}$ values in POME treated soils ranged from $6.28 \pm$ 0.19 to $6.83 \pm 0.24$ There was no significant difference ( $p \leq 0.5)$ in the $\mathrm{pH}$ value of the soils treated with $250 \mathrm{ml}, 500 \mathrm{ml}$ and $1000 \mathrm{ml}$ POME and in the soil treated with $250 \mathrm{ml}, 500 \mathrm{ml}, 1000$ $\mathrm{ml}$ and $2000 \mathrm{ml}$, but there was a significant difference $(p \geq 0.5)$ in the $\mathrm{pH}$ value of the soil treated with $2000 \mathrm{ml}$ of the effluent. There was significant difference $(p \geq 0.05)$ in the $\mathrm{pH}$ values over the duration of pollution (Fig. 1).

\subsection{Organic Matter Content}

The values of organic matter in control $(0 \mathrm{ml})$ soils were in the range of $2.41 \pm 0.23 \%$ and 2.41 $\pm 0.09 \%$. The organic matter content of the soils treated with varying concentrations of POME ranged from $3.53 \pm 0.19 \%$ to $4.97 \pm 0.26 \%$ (Table 6 and Fig. 2).

\subsection{Total Nitrogen Content}

The control soils $(0 \mathrm{ml})$ had the total nitrogen content in the range of $0.06 \pm 0.2 \%$ and $0.06 \pm$ $0.01 \%$. In the soil treated with varying concentrations of POME, the total nitrogen content ranged from $0.08 \pm 0.01 \%$ to $0.10 \pm$ $0.04 \%$. Significant difference $(p \leq 0.5)$ was not observed among concentration. There was no significant difference in total nitrogen content over the duration of study.

\subsection{Effective Cation Exchange Capacity (ECEC)}

The values of ECEC in the control $(0 \mathrm{ml})$ soils were in the range of $9.45 \pm 0.43 \mathrm{cmol} / \mathrm{kg}$ and 9.7 $\pm 0.06 \mathrm{cmol} / \mathrm{kg}$ (Table 5). The value of ECEC in palm oil mill effluent polluted soil increased to between $9.8 \pm 0.14 \mathrm{cmol} / \mathrm{kg}$ and $11.55 \pm 0.30$ $\mathrm{cmol} / \mathrm{kg}$ (Table 6 and Fig. 3). There was significant increase $(p \leq 0.5)$ in ECEC in $2000 \mathrm{ml}$ polluted soil and significance difference $(p \geq 0.5)$ did not exist in $250 \mathrm{ml}, 500 \mathrm{ml}, 1000 \mathrm{ml}$ and that of $250 \mathrm{ml}, 500 \mathrm{ml} 1000 \mathrm{ml}$.

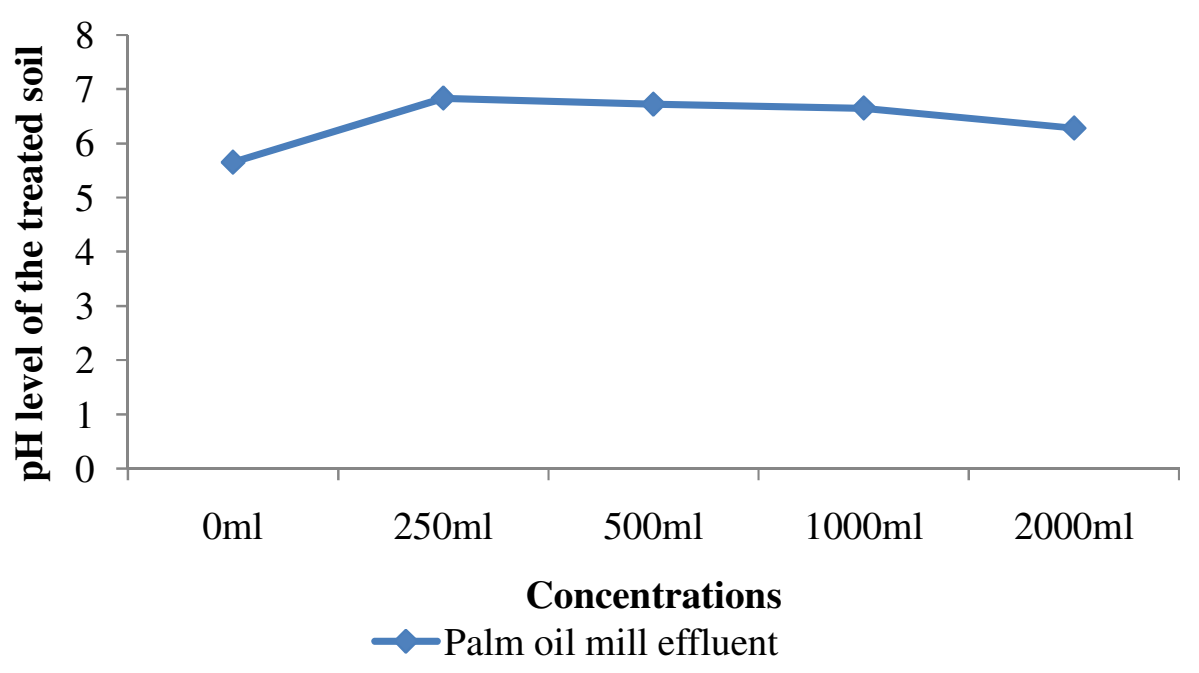

Fig. 1. Effects of concentrations of palm oil mill effluent on the soil pH 


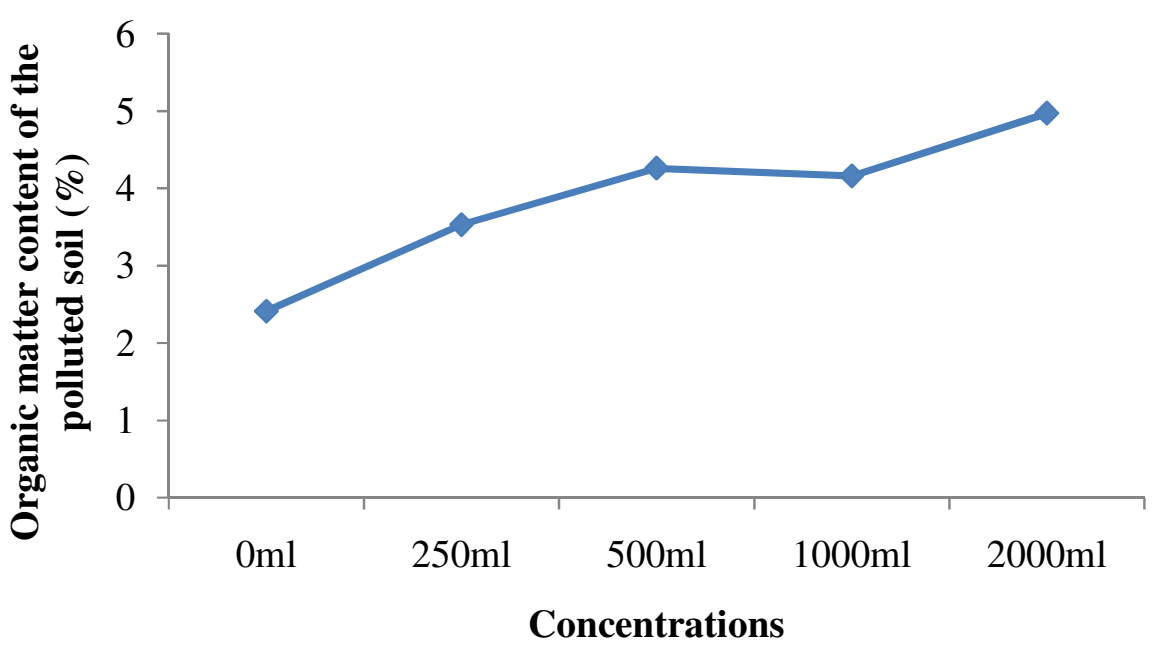

$\neg$ Palm oil mill effluent

Fig. 2. Effects of concentrations of palm oil mill effluents on soil organic matter

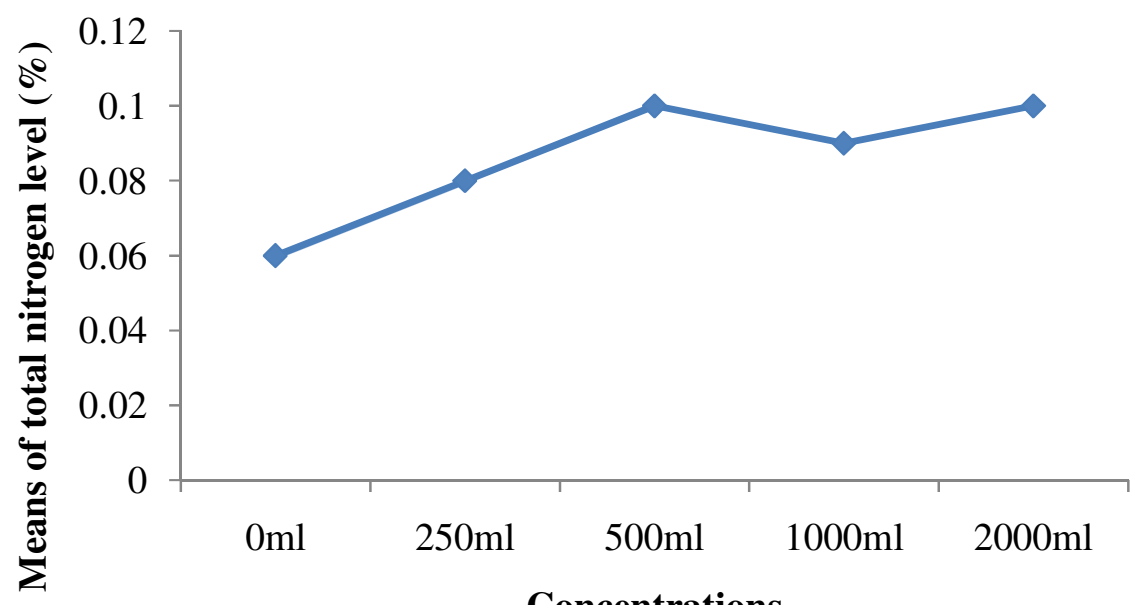

Concentrations

$\neg$ Palm oil mill

Fig. 3. Effects of concentrations of palm oil mill effluent on total nitrogen content of the polluted soil

\section{DISCUSSION}

Soil is a potent system of terrestrial ecosystem. The direct discharge of untreated industrial effluents may have profound influence on the physicochemical and biological properties of the soil. The pollutant level of POME varies with the quality of the raw material and production process used to manufacture the palm oil.

In this study, following pollution of soil with varying concentrations of POME, the soil showed profound changes in the microbial populations and physicochemical properties. In assessing the effects of different concentrations of POME on microbial population, the result showed no significant difference $(p \geq 0.5)$ in THB mean count in $250 \mathrm{ml}$ and $500 \mathrm{ml}$ of effluent polluted soil over the controls. This implies that the THB mean counts in $250 \mathrm{ml}$ and $500 \mathrm{ml}$ the polluted soil fall in the same range with that of the control. Also, there was a significant reduction $(p \leq 0.5)$ in THB in $1000 \mathrm{ml}$ and $2000 \mathrm{ml}$ over the control. These indifferences in THB mean count possesses 
some similar characteristics and hence have the same effect on soil bacteria. Also, the result showed that there was a significant increase $(p$ $\geq 0.5$ ) in THF and THA in $250 \mathrm{ml}$ and $500 \mathrm{ml}$ (Table 2). This increase in fungi population may be attributed to the acidity nature of the effluents, because fungi strive best in acidic environments than bacteria which can only survive in a neutral to alkaline $\mathrm{pH}$ environment. Significant increase $(p \geq 0.5)$ in THA count was also observed in 250 $\mathrm{ml}$ and $500 \mathrm{ml}$ which had THA count higher than the controls. This may also be attributed to the acidic nature of the effluents and the soil since soil actinomycetes have been known to tolerate acidic environment than the true bacteria. Soil actinomycetes can tolerate a $\mathrm{pH}$ level of up to 6.80 , and this was the $\mathrm{pH}$ level in most of the treated soils in this study. An increase in microbial population has earlier been reported [5].

Table 4. Physicochemical properties of the soil before the commencement

\begin{tabular}{ll}
\hline Parameters & Values \\
\hline $\mathrm{pH}$ & 5.60 \\
Electrical conductivity $(\mathrm{ds} / \mathrm{m})$ & 0.055 \\
Organic matter $(\%)$ & 2.41 \\
Total nitrogen $(\%)$ & 0.06 \\
Available phosphorus $(\mathrm{mg} / \mathrm{kg})$ & 31.54 \\
$\mathrm{THC}(\mathrm{mg} / \mathrm{kg})$ & $\mathrm{BDL}$ \\
$\mathrm{Ca}(\mathrm{cmol} / \mathrm{kg})$ & 4.00 \\
$\mathrm{Mg}(\mathrm{cmol} / \mathrm{kg})$ & 2.10 \\
$\mathrm{Na}(\mathrm{cmol} / \mathrm{kg})$ & 0.06 \\
$\mathrm{~K}(\mathrm{cmol} / \mathrm{kg})$ & 0.21 \\
$\mathrm{EC}(\mathrm{cmol} / \mathrm{kg})$ & 1.11 \\
ECEC $(\mathrm{cmol} / \mathrm{kg})$ & 8.82 \\
Base saturation $(\%)$ & 85.16 \\
Sand $(\%)$ & 75.80 \\
Silt $(\%)$ & 12.60 \\
Clay $(\%)$ & 11.60 \\
Lead $(\mathrm{mg} / \mathrm{kg})$ & 6.20 \\
Nickel $(\mathrm{mg} / \mathrm{kg})$ & 9.44 \\
Cadmium $(\mathrm{mg} / \mathrm{kg})$ & 4.32 \\
Chromium $(\mathrm{mg} / \mathrm{kg})$ & 5.60 \\
Iron $(\mathrm{mg} / \mathrm{kg})$ & 919.66 \\
\hline
\end{tabular}

In terms of concentrations of pollution, $250 \mathrm{ml}$ of the effluents was found to be most favourable concentration for the proliferation of microorganism, followed by $500 \mathrm{ml}$ in this study. Similar result had earlier been reported [12]. He observed that effluent impacted soil at low concentration encouraged proliferation of microorganisms but at high concentration, inhibits the same [12], this was also observed in this study and could be attributed to the harmful level of the effluent at higher concentrations (Table 2). The components of the POME used in this study revealed that the effluents contain some metabolizable nutrients for the soil microorganisms and excess of these nutrients with the high water content suppressed the microorganisms [12]. Excess water in soil restricts microorganisms and their activities by preventing oxygen movement into and through the soil in sufficient quantity to meet the oxygen demand of the microorganisms $[23,24]$.

Also in assessing the effect of duration of pollution and different concentrations of pollution on microbial population, THB showed significant increase $(p \geq 0.1)$ with decrease in concentrations of pollutions and significant reduction with increase in the duration of pollution (Table 3 ). This result implies that there was a steady reduction in THB with increase in concentrations and duration of pollution. Also, the THF mean counts at $250 \mathrm{ml}$ showed significant increase $(p \geq 0.5)$ after 8 weeks of pollution and a significant reduction was observed in the same concentration of pollution after 16 weeks of pollution and while there was no significant difference in THF count at $500 \mathrm{ml}$, $1000 \mathrm{ml}$ of after 8 weeks and 16 weeks of pollution (Table 3). Similarly, there was significant increase $(p \geq 0.5)$ in THA at $250 \mathrm{ml}$, $500 \mathrm{ml}$, after 8 weeks of pollution and $250 \mathrm{ml}$ after 16 weeks of pollution, and no significant difference was also observed in THA in $1000 \mathrm{ml}$, $2000 \mathrm{ml}$ after 8 weeks of pollution and $500 \mathrm{ml}$, $1000 \mathrm{ml}$ and $2000 \mathrm{ml}$ after 16 weeks of pollution. This result implies that, there was a significant increase $(p \geq 0.5)$ in THB, THF and THA in all the soil samples, followed by a reduction in THB and THF after 16 weeks of pollution except THA which did not show reduction after 16 weeks of pollution (Table 3 ).

The result of this study also showed changes in physicochemical properties. This change has earlier been reported that continual applications of effluents on the soil can change soil properties, e.g. $\mathrm{pH}$ and nutrient concentrations [25].

The result also showed that there was a significant increase $(\mathrm{p} \geq 0.5)$ in the $\mathrm{pH}$ values in all the soil polluted with POME over the control. Increase in $\mathrm{pH}$ in POME polluted soil is in agreement with the report of Okwute and Isu [5], who reported that when raw POME is discharged into the soil, the acidic $\mathrm{pH}$ seems to gradually increase to alkaline as biodegradation takes 
Table 5. Effects of concentrations of pollution on the physiochemical properties of the soil polluted with palm oil mill effluent

\begin{tabular}{lllllll}
\hline & $\mathbf{0 ~} \mathbf{~ l}$ & $\mathbf{2 5 0} \mathbf{~} \mathbf{l}$ & $\mathbf{5 0 0} \mathbf{~} \mathbf{l}$ & $\mathbf{1 0 0 0} \mathbf{~} \mathbf{l}$ & $\mathbf{2 0 0 0} \mathbf{~} \mathbf{l}$ & $\mathbf{L S D}$ \\
\hline $\mathrm{pH}$ & $5.65^{\mathrm{c}} \pm 0.50$ & $6.83^{\mathrm{a}} \pm 0.24$ & $6.72^{\mathrm{a}} \pm 0.20$ & $6.65^{\mathrm{a}} \pm 0.18$ & $6.28^{\mathrm{b}} \pm 0.19$ & 0.20 \\
Organic matter & $2.41^{\mathrm{a}} \pm 0.23$ & $3.53^{\mathrm{c}} \pm 0.19$ & $4.26^{\mathrm{b}} \pm 0.26$ & $4.16^{\mathrm{b}} \pm 0.26$ & $4.97^{\mathrm{a}} \pm 0.26$ & 0.18 \\
Avail. P & $31.54^{\mathrm{a}} \pm 2.64$ & $71.1^{\mathrm{c}} \pm 1.24$ & $14.49^{\mathrm{b}} \pm 2.02$ & $11.49^{\mathrm{b}} \pm 1.05$ & $15.42^{\mathrm{a}} \pm 1.18$ & 0.85 \\
Total N & $0.06^{\mathrm{c}} \pm 0.02$ & $0.08^{\mathrm{b}} \pm 0.01$ & $0.10^{\mathrm{b}} \pm 0.03$ & $0.09^{\mathrm{b}} \pm 0.02$ & $0.10^{\mathrm{b}} \pm 0.04$ & 0.02 \\
Mg & $2.37^{\mathrm{a}} \pm 0.09$ & $2.73^{\mathrm{b}} \pm 0.11$ & $2.13^{\mathrm{a}} \pm 0.08$ & $2.64^{\mathrm{c}} \pm 0.14$ & $3.25^{\mathrm{a}} \pm 0.09$ & 0.09 \\
Sodium (Na) & $0.09^{\mathrm{b}} \pm 0.03$ & $0.11^{\mathrm{b}} \pm 0.01$ & $0.11^{\mathrm{b}} \pm 0.02$ & $0.12^{\mathrm{b}} \pm 0.01$ & $0.12^{\mathrm{b}} \pm 0.04$ & 0.04 \\
Calcium (Ca) & $4.75^{\mathrm{a}} \pm 0.10$ & $5.18^{\mathrm{a}} \pm 0.9$ & $5.31^{\mathrm{a}} \pm 0.08$ & $5.40^{\mathrm{a}} \pm 0.05$ & $5.50^{\mathrm{a}} \pm 0.08$ & 0.61 \\
Ec & $0.05^{\mathrm{b}} \pm 0.01$ & $0.13^{\mathrm{a}} \pm 0.02$ & $0.14^{\mathrm{a}} \pm 0.01$ & $0.15^{\mathrm{a}} \pm 0.03$ & $0.17^{\mathrm{a}} \pm 0.02$ & 0.02 \\
Base saturation & $78.52^{\mathrm{b}} \pm 2.01$ & $78.32^{\mathrm{b}} \pm 1.53$ & $78.06^{\mathrm{b}} \pm 0.69$ & $78.27^{\mathrm{b}} \pm 0.89$ & $80.09^{\mathrm{a}} \pm 1.14$ & 1.35 \\
K & $0.21^{\mathrm{b}} \pm 0.02$ & $0.29^{\mathrm{a}} \pm 0.03$ & $0.23^{\mathrm{b}} \pm 0.01$ & $0.16^{\mathrm{b}} \pm 0.09$ & $0.29^{\mathrm{a}} \pm 0.08$ & 0.02 \\
EFEC & $9.45^{\mathrm{b}} \pm 0.43$ & $10.61^{\mathrm{b}} \pm 0.21$ & $9.8^{\mathrm{b}} \pm 0.14$ & $10.63^{\mathrm{b}} \pm 0.08$ & $11.55^{\mathrm{a}} \pm 0.30$ & 0.69 \\
EA & $2.03^{\mathrm{a}} \pm 0.8$ & $2.3^{\mathrm{a}} \pm 0.05$ & $2.15^{\mathrm{a}} \pm 0.04$ & $2.31^{\mathrm{a}} \pm 0.08$ & $2.3^{\mathrm{a}} \pm 0.02$ & 0.20 \\
\hline
\end{tabular}

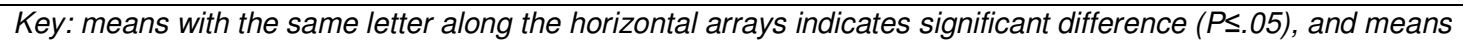
with different letter along the column indicates no significance difference $(P \geq .05)$

Table 6. Effects of duration of pollution on physico- chemical properties of the soil polluted with palm oil effluent

\begin{tabular}{llll}
\hline & $\mathbf{8}$ weeks & $\mathbf{1 6}$ weeks & LSD \\
\hline pH & $6.6^{\mathrm{b}} \pm 0.08$ & $6.25^{\mathrm{a}} \pm 0.04$ & 0.13 \\
Organic matter & $4.02^{\mathrm{a}} \pm 0.10$ & $3.71^{\mathrm{a}} \pm 0.09$ & 0.11 \\
Avail. P & $18.31^{\mathrm{b}} \pm 0.24$ & $19.7^{\mathrm{a}} \pm 0.36$ & 0.54 \\
Total N & $0.09^{\mathrm{b}} \pm 0.02$ & $0.08^{\mathrm{b}} \pm 0.02$ & 0.01 \\
$\mathrm{Mg}$ & $2.87^{\mathrm{a}} \pm 0.10$ & $2.37^{\mathrm{c}} \pm 0.05$ & 0.06 \\
$\mathrm{Na}$ & $0.13^{\mathrm{b}} \pm 0.02$ & $0.09^{\mathrm{a}} \pm 0.02$ & 0.02 \\
$\mathrm{Ca}$ & $5.38^{\mathrm{a}} \pm 0.11$ & $5.00^{\mathrm{a}} \pm 0.09$ & 0.38 \\
$\mathrm{Ec}$ & $0.13^{\mathrm{a}} \pm 0.02$ & $0.13^{\mathrm{a}} \pm 0.01$ & 0.01 \\
$\mathrm{Bs}$ & $79.19^{\mathrm{a}} \pm 2.10$ & $78.25^{\mathrm{a}} \pm 1.80$ & 0.86 \\
$\mathrm{~K}$ & $0.22^{\mathrm{b}} \pm 0.02$ & $0.25^{\mathrm{a}} \pm 0.03$ & 0.01 \\
ECEC & $10.86^{\mathrm{a}} \pm 0.28$ & $10.02^{\mathrm{b}} \pm 0.20$ & 0.44 \\
$\mathrm{EA}$ & $2.26^{\mathrm{a}} \pm 0.09$ & $2.18^{\mathrm{a}} \pm 0.08$ & 0.13 \\
\hline
\end{tabular}

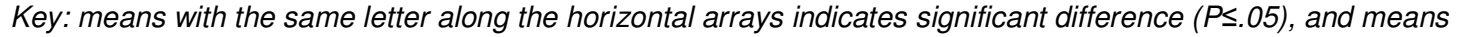
with different letter along the column indicates no significance difference $(P \geq .05)$.

place, and this was the case in this study as $\mathrm{pH}$ of the polluted soils increases from $5.65 \pm 0.05$ in the control to between $6.28 \pm 0.19$ and $6.83 \pm$ 0.24 . The increase in $\mathrm{pH}$ of POME polluted soil has also been earlier reported [12,24].

The polluted soils were also characterised by increased in organic matter and total nitrogen. Organic matter of a soil is usually determined and reported as a measure of organic carbon. Organic matter content strongly affects soil fertility by defining the energy supply to microorganisms, availability and quality of substrates and the biodiversity necessary to sustain much soil functions $[17,19,26]$.

\section{CONCLUSION}

This study on the effects of palm oil mill effluent on soil microflora and fertility showed that the mean counts of total heterotrophic bacteria, total heterotrophic fungi and total heterotrophic actinomycetes increased with decrease in concentration of pollution and decreased with increase in the duration of pollution in the soils. Similarly, the POME also caused profound changes on the soil physicochemical properties of the polluted soils.

The result revealed significant differences in soil $\mathrm{pH}$, organic matter content, total nitrogen, available phosphorus, magnesium, electrical conductivity, percentage base saturation, potassium and effective cation exchange capacity between polluted and non-polluted soil while no significant difference was observed in calcium, sodium and exchangeable acidity between polluted and non-polluted soil. 
In conclusion, this study revealed that POME could be harmful to the soil if not properly managed and also useful to the soil if properly discharged since light application of the effluents could enhance microbial proliferation which enhances soil fertility. Therefore, government should create awareness to those involved in small and large scale palm oil processing on the need for proper disposal of effluent because if not properly managed, it can negatively affect soil fertility by inhibiting microbial proliferation.

\section{ACKNOWLEDGEMENT}

I sincerely acknowledge the immense contributions of all authors.

\section{COMPETING INTERESTS}

Authors have declared that no competing interests exist.

\section{REFERENCES}

1. Láng I. Environmental management and sustainable development. In Nath, B., Hens, L. and Devuyst, D (Eds.). Environmental Management. Instruments for Implementation Brussels: VUB University Press, VUB University. 1993;3.

2. Nagaraju M, Narasimha G, Rangaswami $V$. Influence of sugar industry effluents on soil enzyme activities. Ecol. Environ. Cons. 2009;15:89-94.

3. Ahmad A, Ismail S, Bhatia S. Water recycling from palm oil mill effluent (POME) using membrane technology. Desalination. 2003;157:87-95.

4. Abdul LA, Suzylawati I, Norliza I, Subhas B. Removal of suspended solids and residual oil from palm oil mill effluents. J. Chem. Tech. Biotech. 2003;78(9):971-978.

5. Okwute OL, Isu RN. Impact analysis of palm oil mill effluent on the aerobic Bacterial density and ammonium oxidizers in a dumpsite in Anyigba, Kogi State. Afr. J. Biotech. 2007;6(2):116-119.

6. Bek-Nielsen C, Singh G, Toh TS. Bioremediation of palm oil mill effluent. In: Proceedings from International Palm Oil Congress. Kuala Lumpur, Malaysia; 1999.

7. Chan KW, Watson I, Lim KC. Use of oil palm waste material for increased production. Paper presented at the Conference on Soil Science and Agricultural development inMalaysia, Kuala Lumpur, Malaysia; 1980.
8. Ngan MA, Zajima $Y$, Asahi M, Junit HA. Novel treatment processes for palm oil mill effluent. Proim Technology; 1996.

9. Aggelis GC, Gavala HN, lyberatos G. Combined and separated aerobic and anaerobicbio-treatment of green olive debittering wastewater. J. Agric Eng. Res. 2001;80(3):283-292.

10. Ma AN. Environmental management for thepalm oil industry. Palm Oil Dev. 2000; $30: 1-9$

11. Arias ME, Jose AG, Gonzalez-Villa FJ, Ball AS. Soil heath: A new challengeto microbiologist and chemists. Soil Heath Int. Microbial. 2005;8:13-21.

12. Nwaugo VO, Chinyere GC, Inyang CU. Effects of palm oil mill Effluents (pome) on soil Bacterial flora and Enzyme activitiesin Egbama. Plant Product Research Journal. 2008;12:10-13.

13. Orhue ER, Uzu OF, Osaigbovo AU. Effect of combining rubber effluent with rock phosphate on some soil chemical properties and early growth of maize (Zea mays. L). International Journal of Soil Science. 2007;2:82-95.

14. Antai SP, Unimke AA, Agbor RB. Assessment of the heterotrophic and crude oil utilizing microorganisms of imo river estuary of the Niger Delta mangrove ecosystem. American International Journal of Biology. 2014;2(1):29-42.

15. Mill. A sustainable waste management practice. Review in Environmental Scienceand Biotechnology.

DOI: 10. 1007/s11157 - 010-9199-2.

16. Holt JG, Krieg NR, Senath PH, Stanley LT. Williams ST. Bergey's manual of determinative bacteriology $\left(9^{\text {th }} \quad \mathrm{Ed}\right)$. Baltimore, Willams and Wilkins; 1994.

17. Unimke AA, Antai SP, Agbor RB. Influence of seasonal variation on the microbiological and physicochemical parameters of imo river estuary of the Niger Delta mangrove ecosystem. American International Journal of Biology. 2014;2(1):61-74.

18. Day PR. Particle fractionation and particlesize analysis. In: C. A Black (eds).Determination of phosphorus in Natural waters. Analytical Chemistry. ACTA. 1965;27:31-38.

19. Nelson DW, Sommers LE. Total carbon, organic carbon and matter. In: Page, A. L., Miller, R. H. and Keeney, D. R. (eds.) Methods of Soil Analysis, Part 2 Chemical and Microbiological Properties. Madison, Wisconsin. 1982;539-579. 
20. Bremmer JM. Total Nitrogen. In: D. L. Spark (eds). Methods of soil analysis. Part 3-chemical methods, SSSA Book Series 5, Madison, Wisconson; 1996.

21. Bray $\mathrm{RH}$, Kurtz LT. Determination of total, Organic and available forms of phosphorus in soils. Journal of Soil Science. 1945;(5): 35-45.

22. Udo EJ, Ibia TO, Ogunwale JA, Ano AO. Esu IE. Manual of soil, plant and water analysis. Sibon Books Limited, Lagos; 2009.

23. Paul EA, Clark FE. Soil microbiology and biochemistry. Academic Press Incorporated San Diego, California. 1989; 11-234.
24. Lim KH. Trail on long term effects of application of palm oil mill effluent on soil properties, oil palm nutrition and yields. Proc. cont. Agric; 1987.

25. Tubonimi JK, Patricia UA, Herbert OS, Amonia OB. Impact of palm oil mill effluenton water quality. Res. J. Appl. Sci. $2007 ; 2(7): 842-845$.

26. Unimke AA, Antai SP, Agbor RB, Nseabasi $\mathrm{NO}$, Agbo BE. Evaluation of seasonal variation in the microbial and heavy metal concentrations of Imo river estuary of the Niger Delta Mangrove ecosystem. Advance Research in Agriculture and Veterinary Science. 2014; 1(2):88-94.

(c) 2017 lyakndue et al.; This is an Open Access article distributed under the terms of the Creative Commons Attribution License (http://creativecommons.org/licenses/by/4.0), which permits unrestricted use, distribution, and reproduction in any medium, provided the original work is properly cited.

Peer-review history:

The peer review history for this paper can be accessed here: http://sciencedomain.org/review-history/19194 